\title{
Liberal Intervention in the Foreign Policy Thinking of Tony Blair and David Cameron
}

\begin{abstract}
David Cameron was a critic of Tony Blair's doctrine of the international community, which was used to justify war in Kosovo and more controversially in Iraq, suggesting caution in projecting military force abroad while in opposition. However, and in spite of making severe cuts to the defence budget, the Cameron-led Coalition government signed Britain up to a military intervention in Libya within a year of coming into office. What does this say about the place liberal interventionism occupies in contemporary British foreign policy? To answer this question, this article studies the nature of what we describe as the 'bounded liberal' tradition that has informed British foreign policy thinking since 1945, suggesting that it puts a distinctly UK national twist on conventional conservative thought about international affairs. Its components are: scepticism of grand schemes to remake the world; instinctive Atlanticism; security through collective endeavour; and anti-appeasement. We then compare and contrast the conditions for intervention set out by Tony Blair and David Cameron. We explain the similarities but crucially also the vital differences between the two leaders' thinking on intervention, with particular reference to Cameron's perception that Downing Street needed to loosen its control over foreign policy-making after Iraq. Our argument is that policy substance, policy style and party political dilemmas prompted Blair and Cameron to reconnect British foreign policy with its ethical roots, ingraining a bounded liberal posture to British foreign policy after the moral bankruptcy of the John Major years. This return to a patient, pragmatic and ethically informed foreign policy meant that military operations in Kosovo and Libya were undertaken in quite different circumstances, yet came to be justified by similar arguments from the two leaders.
\end{abstract}

Key words: David Cameron; Tony Blair; foreign policy; Kosovo; Libya; intervention 


\title{
Liberal Intervention in the Foreign Policy Thinking of Tony Blair and David Cameron
}

\author{
'Then he began to reflect. But his thoughts only returned to what had just \\ happened, to the strict past, the past that seems deceptively like the present' \\ (Bolaño 2009: 93).
}

\section{Introduction}

Close observers of British foreign policy usually remark on how rare it is to find sudden or unexpected foreign policy ruptures brought about either by a change of Prime Minister leading the same majority government, or following a change in the main party of government itself (Theakston 2004). Continuity rather than change has been the order of the day in a realm where 'disagreement on foreign policy issues has tended to be on emphasis, timing and detail, and has not extended to the main principles' (Shlaim 1977: 26). In this view, even overtly ideological prime ministers such as Margaret Thatcher in the 1980s struggled to engender anything more than 'marginal rather than decisive' breaks with past tradition (Vickers 2011b: 124), stylistic change rather than policy innovation being the order of the day. Some writers suggest that cross-party consensus stems from the fact that foreign policy deals with the overarching pursuit of security in the national interest, conceived as existing above the day to day politicking that accompanies debate over domestic issues. 'Ideology is always difficult to translate into action, and foreign policy is an area which time and again blunts ideological fervour in favour of a more cautious pragmatism' (Clarke 1988: 84). Other writers, notably Paul Kennedy, suggest that economic decline has limited Britain's room for manoeuvre, as financial troubles have 'overshadowed, ominously, continuously, restrictively, almost every consideration of the country's external role and have thus been the greatest influence of all on the country's decline as a major power' (Kennedy 1985: 320). In this context, the energy that could have been put into ideological squabbles between the parties has been diverted to managing decline rather than carving out a potentially more distinctive role in the world. Furthermore, the complex, cross-departmental nature of the issues at stake engage participants in a policy process that, when put in motion, is difficult to alter by more than a few degrees, let alone reverse altogether. As John Saville has argued, relative continuity has been the demonstrable feature of British political life in the twentieth century, yet, significantly: 'No department of State has illustrated the process of continuity in more impressive fashion than the Foreign Office after 1945' (Saville 1993: 12).

Ideology does, however, comes in many strengths, shapes and sizes, and part of the explanation for what Guy de Carmoy (1971: 345) has described as a 'bipartisan' approach to foreign policy is that parties of government have settled on what we describe in this article as a 'bounded liberal' interpretation of international affairs that underpins their foreign policy practice. Bounded liberalism mixes together elements of progressivist faith in human nature and faith in international institutions to regulate the excesses of state behaviour with a hardheaded realist appreciation of global politics, the realist view being that 'international relations remains and will always be a realm of unceasing struggle' (Hall \& Rengger 2005: 75-76). We focus in the article on the fate of bounded liberalism in recent British foreign policy thought, because in recent years a robust debate has emerged over New Labour's legacy to British foreign policy and the nature of the ideas underlying Conservative-Liberal foreign policy practice (see Dodds \& Elden 2008; Beech 2010; Morris 2010; Bratberg 2011; Daddow \& Gaskarth 2011). However, our article does feed into the critical literature on 
conservatism in international relations which argues that morality has never been absent from the realist tradition in international relations popularised by Hans Morgenthau and Kenneth Waltz (Morgenthau 1985; Waltz 1959; Walker 1993; Hall \& Rengger 2005), a hypothesis we are able to test using data from the language of foreign policy in the UK. For example, in his memoirs Blair referred to William Gladstone's campaign against the Turkish massacres of Bulgarians in the 1880s when rejecting the idea of an opposition between defending the national interest and upholding moral values: 'a traditional foreign policy view, based on a narrow analysis of national interest and an indifference unless that interest is directly engaged, is flawed and out of date. I happen to think as Gladstone did that it is also immoral: but even if I didn't, I am sure that in the early twenty-first century, it doesn't work' (Blair 2010: 225. On the Gladstone in Blair see Meyer 2010: 199). Current Foreign Secretary William Hague has agreed: 'It is not in our character to have a foreign policy without a conscience: to be idle or uninterested while others starve or murder each other in their millions is not for us' (Hague 2009). Such obviously ethically loaded sentiments compel attention to the oft-neglected ethical context underpinning conservative thought on international affairs, but to avoid terminological confusion between small 'c' (theoretical approaches to conservatism) and capital ' $C$ ' (Conservative Party) we have opted to label this UK national style of foreign policy thought 'bounded liberalism'.

Our article links the theoretical work on international thought with the empirical study of British foreign policy by analysing the British approach to liberal interventionism since the 1990s. We studied the language used by Tony Blair to justify and explain British involvement in Operation Allied Force in Kosovo in March 1999 and compared it to David Cameron and William Hague's explanations for UK involvement in what became the NATOled Operation Unified Protector in Libya twelve years later. We wanted to compare and contrast the foreign policy traditions on which they drew to inform their practice by way of coming to a judgement about the extent of continuity and change in recent British foreign policy. The timing of each intervention was crucial, and arguably legacy-forming in both cases. Blair was noticeably light on foreign policy thinking before he came to office, and for all his talk of 'new-ness' articulated what he did not want to do (be like his Conservative predecessor John Major) better than he set out clear prescriptions which could be his 'vision' for British foreign policy. His foreign policy came to be best remembered for his 'doctrine of international community', yet this was forced upon him by the acute humanitarian emergency in Kosovo rather than being the logical corollary of what had preceded it - because Robin Cook's 'ethical dimension' never really found much favour in Downing Street and the memorable 'just war' elements of the speech found their way into the speech in rather a haphazard fashion (Daddow 2009). By the time of Kosovo, moreover, ethical questions over arms sales to African regimes accused of human rights abuses, such as Sierra Leone, had become sticks with which to beat the Foreign Office (Press Association 1999), surely reducing the Prime Minister's willingness to open more flanks to criticism unless compelled to by events.

Cameron, similarly, had most probably not anticipated being confronted with a humanitarian crisis and the question of whether to intervene militarily in an Arab country so soon after the Iraq fiasco. His dilemma was even more acutely felt given the context of great economic difficulty at home, necessitating deep cuts in the defence budget. He had previously approached the idea of humanitarian intervention with some caution and was not a neo-conservative, although he was surrounded by some, such as Michael Gove who, as we shall see below, were inclined to agree with that line of thinking (Dodds \& Elden 2008: 356). During the first few months of the Coalition government in 2010, as illustrated in the Strategic Defence and Security Review (SDSR), caution still reigned as Cameron fell back, not always successfully (Gaskarth 2010), on the time honoured levers of Conservative 
foreign policy such as reinvigorating the Commonwealth and deepening UK plc's trade connections with 'emerging economies' (Vickers 2011: 211-12). This return to essentials was a result of Cameron's obvious intention to distance himself from Blair, as the Conservative Party sought in turn to distance itself from New Labour's perceived recklessness in foreign policy.

Our article sets out to answer a central research question: what impact, if any, did the transition in June 2010 from New Labour to the David Cameron-led Conservative-Liberal government have on thinking about interventionism as a tool of British foreign policy? Drawing on interpretivist methods we study what current and recent foreign policy practitioners in government have had to say about humanitarian intervention as a prism through which they articulate wider arguments about Britain's interests and role in the world. In the first section we survey the rationale for taking an interpretivist approach to the data and outline our use of traditions and dilemmas that creates the framework for the analysis that follows in the rest of the article. In the second section we consider the component parts of the post-1945 bounded liberal British foreign policy tradition on which the leaders drew, conceptualising it as being characterised by: scepticism of grand schemes to remake the world; instinctive Atlanticism; security through collective endeavour; and anti-appeasement sentiment. The final section considers the crucial variables accounting for the change of emphasis from Blair to Cameron on the issue of the conditions they wanted to satisfy when deciding on the rectitude of launching an intervention operation. We show that Cameron's conditions have to be seen as a response to the hubris Bair exhibited in developing his highly personalised and limited conditions. In other words, Cameron's dilemma was not only a policy one (what to do in Libya), but also a party political and presentational one (how to justify Libya in a manner that would not resurrect the thorny debates that erupted over Iraq from 2003 and had been rumbling on during the Chilcot enquiry that spanned the Conservative-New Labour change of government.

Our arguments below are twofold. The first is that, as a direct response to the poverty of realism evident during the Major years, Blair and Cameron (albeit in slightly different ways) put principles back to the heart of UK foreign policy, settling on liberal interventionism as a way of embracing a 'modern' role for Britain in the world whilst harking back to the time-honoured principles of realist thought in international relations. The bounded liberal tradition defines the parameters of what the main parties of government perceive as acceptable and unacceptable in British foreign policy conduct. Our second argument is that close attention to the language of foreign policy creates space for us to discern the similarities across parties of government whilst remaining sensitive to the nuances between them. Blair and Cameron might have agreed on the principle of intervention as part of a bounded liberal foreign policy strategy for the UK, but key differences between them remain. Cameron has been much more cautious than Blair in setting down conditions for violations of the Westphalian notion of state sovereignty that might lead to a form of moral crusade that mired Britain and the US in Iraq. Cameron's interventionism, therefore, has been characterised by a concerted effort to divorce himself from the messianic moral fervour of the post-9/11 Blair. Cameron's approach in fact mimics the first term Blair (1997-2001). This was a Blair lacking a firm foreign policy vision and who therefore turned to the bounded liberal tradition popular in establishment Britain as a way of framing his approach to the conduct of foreign policy.

\section{Interpreting foreign policy traditions}

Our article unpacks the idea of a bounded liberal tradition in British foreign policy using the Kosovo and Libya dilemmas as nodal points at which we see this tradition being reasserted. It is therefore important to begin with a study of what we mean by 'traditions and dilemmas' and how we have accessed them in the data. Interpretivists are interested in the study of 
meanings and processes of meaning-making, privileging forms of data gathering that seek to unpack the beliefs individuals hold about themselves and others in society. Interpretivism entails an epistemological critique of positivism and advances the cause of a historicist methodology, and we will deal with each of these features in turn by way of providing the theoretical backdrop to the article.

First, interpretivists are sceptical about the positivist epistemology underpinning the research agenda of large portions of what has conventionally passed for political science, certainly as practiced in the US and UK (a characterisation of the discipline challenged in Smith 2008: 144). Interpretivists 'reject the idea of given truths, whether based on pure reason or pure experience'; they 'look suspiciously on any claim to describe neutrally an external reality'; and they 'emphasise the constructed nature of our claims to knowledge' (Bevir \& Rhodes 1999: 223). This anti-foundationalist position does not deny the existence of some form of reality; rather, it is sceptical of the claim that there is a reality 'out there' waiting to be discovered by the careful, detached researcher. It is the nature of our access to reality rather than the existence of reality that is called into question. Reality for interpretivists is not given to us but made by us, hence its affinities with constructivism in the study of International Relations. In this view, 'facts are not given but constructed' (Bevir and Rhodes, 1999: 226) and interpretivist researchers are charged with the task of critiquing the ways in which we have come to believe we 'know' the world, and the representational practices involved in engaging with the world.

The second noteworthy feature of interpretivism is that, through a genealogical approach, it is attentive to the historical context of political action: 'If we are to explain actions and practices, we have to show how they happened historically to arise' (Bevir 2011: 88). Interpretivists explore the historicist elements of the beliefs people hold about the world, whilst also paying attention to contingencies, or the unexpected departure from traditions, arising from the ways in which individuals or groups bring about change when confronted with 'dilemmas' that force them to reconsider their existing beliefs (Bevir and Rhodes, 1999: 226). This twist on the structure-agency problem in the study of politics leaves plenty of scope for unpredictability in explaining people's actions, whilst also fixing our gaze firmly on the background traditions that inform the beliefs individuals hold about the world.

A 'tradition' is defined as 'a set of theories or narratives and associated practices that people inherit, which provide the background against which they form beliefs and perform actions' (Bevir and Rhodes 1999: 224). Traditions help mould, but they do not determine, the beliefs people come to hold, and interpretivists do not agree with the frequently heard epithet in politics that where you stand depends on where you sit. As Mark Bevir has argued: 'People formulate their intentions in a creative process undertaken against the background of a discourse or tradition' (Bevir 2002: 23). For Rod Rhodes (2007: 1250) a tradition 'is a set of understandings someone receives during socialization'. However, traditions neither determine nor fix beliefs in any simple sense, so we cannot simply read off or ascribe beliefs to individuals by knowing about the traditions they might have inherited; the interpretivist world is more complex than that. As Bevir has argued in work with Rod Rhodes, 'Traditions are contingent, constantly evolving, and necessarily located in a historical context'. An important part of the interpretivist enterprise is to appreciate both the influence and mutability of traditions by 'tracing the appropriate historical connections back through time' (Bevir \& Rhodes 1999: 224-225). A form of 'situated agency' is ultimately what underpins the interpretivist perspective (Bevir 2011: 89-90), with the 'solidity' of ideational frameworks never being 'absolute' (Kabele 2010: 331). From this we can see that the interpretivist focus is, importantly, on change as much as stasis. People confront dilemmas which prompt them constantly to reconfigure the connections between sets of beliefs they hold about the world against the traditions they have been socialised into. 
Interpretivism has made itself felt in the study of politics and International Relations in a number of ways, of which two stand out. First, it has been used to study traditions of political thought that underpin contemporary political practices. For example, Bevir and Rhodes have used interpretivism to decentre the classic 'Westminster model' of government around the idea of 'network governance' (Bevir \& Rhodes 1999; Rhodes 2007). Bevir has, further, traced the ways in which the architects of New Labour melded traditions of political thought associated with libertarian socialism together with social scientific ideas about the merits of the New Public Management (NPM) to inspire many of its domestic reforms in Britain after 1997 (Bevir 2005). Katy Wilkinson has used interpretivist methods to appreciate how individuals in the UK Department for the Environment and Rural Affairs saw their day to day work and the identity of their department within the wider Whitehall machine. As with the work of Bevir and Rhodes, this anthropologically-inclined study involved interviews which helped 'explore beliefs in the context of actors' lived experience' (Wilkinson 2011: 962), an approach replicated in Birgette Poulsen's investigation of civil servants' lived experiences in Danish public administration (Poulsen 2009). Finally, Mark Bevir, Oliver Daddow and Ian Hall have used interpretivist approaches to generate fresh insights into contemporary practices of 'security' in different parts of the globe (Bevir, Daddow \& Hall, in preparation).

Second, there are growing numbers of discourse accounts that implicitly draw on interpretivism by going beyond the depiction of discourses as rigid structures that are immutable to change. For example, Charlotte Epstein (2008) has studied the rise to prominence of transnational anti-whaling discourses since the 1970s. Stephen Dyson has interpreted New Labour's foreign policy by studying the belief system of Tony Blair and Gordon Brown as expressed in statements to the House of Commons and related primary material (Dyson 2009; Dyson 2011). Oliver Daddow's account of New Labour's foreign policy discourses seeks out the historically-informed, traditionalist elements of Tony Blair and Gordon Brown's thinking on the UK's external relations, whilst flagging up the elements of novelty they introduced in response to perceived dilemmas they faced over the thorny question of 'Europe' from 1997-2010 (Daddow 2011). This work has been extended to compare and contrast Margaret Thatcher and Tony Blair's European policy discourses (Daddow forthcoming 2013), as well as those of 'New' and 'Old' Labour more generally (Broad \& Daddow 2010). These accounts bounce between policy and representational practices on the one hand, whilst on the other situating the beliefs agents came to hold against the backdrop of pre-existing traditions of thought about the issues at hand. Crucially, the focus in all these studies is on change as much on how the status quo is maintained in the respective realms of language and practice. Having considered the concept of traditions and dilemmas that informs our article we can now unpack the component parts of the conservative tradition in UK foreign policy.

\section{The post-1945 foreign policy tradition in Britain}

It is by no means easy to define a 'conservative' foreign policy tradition in the UK that would generate a consensus across the board. The starting point for us was the work of Ian Hall and Nicholas Rengger (2005) who have categorised variations on conservative thought in its widest context and then applied it to conservative approaches to international affairs in the UK and US. Most conservatives, they suggest, would agree that 'cautious prudence' should characterise a nation's foreign policy; that interests must come first; that those interests must be legitimate and lawfully pursued; and that there must be respect for other nations which may seek to pursue different interests than one's own - with the same conditions about legitimacy and lawfulness in operationalising those interests diplomatically and militarily. This, they say, is very much a pluralist 'English School' approach to international affairs, 
which has been squeezed out of the picture since the turn of the century when neoconservative thinkers began to demand conformity to global democratic norms rather than unity in diversity (Hall \& Rengger 2005: 72-73). Our analysis of the conservative foreign policy tradition ties the general picture painted by Hall and Rengger to the specifically UKfocus of Øivind Bratberg, who posits that five guiding principles have operated within British foreign policy since 1945:

a privilege for Anglo-American relations, with NATO as corollary; insular reserve towards the European continent; a maintained global presence with special preference for the Commonwealth; a policy based on pragmatism rather than principle; and, finally, a liberal belief in international trade (Bratberg 2011: 331).

We do not disagree with Bratberg's general argument but have chosen to give our study of the traditions a greater focus on security in two ways. First, we have merged his first three principles into one (the extent of Britain's Europeanism and preference for closer Commonwealth relations seemingly being relative to London's preference for the 'special relationship' at any given moment). Second, we added an explicit 'anti-appeasement' element to the tradition which we believe better reflects the focus of our study. Our recategorisation of Bratberg's principles is more about emphasis than substance, reflecting our analytical emphasis on interpretivism. Our four components of the post-1945 foreign policy tradition thus run as follows.

\section{i. Scepticism of grand schemes to remake the world}

This realist element of conservatism critiques the idealism associated with the likes of President Woodrow Wilson in the years 1919-39. Perish the thought, the moral of this story goes, that the United Nations should risk 'becoming just another League of Nations' (Cameron 2011a), 'hobbled' at birth (Meyer 2010: 69, and see 202-31), or a 'talking shop' which could not back its words with credible action on the ground. It argues that the world is not remade according to utopian visions but by incremental change that takes account of unexpected developments brought about in particular by the defects in human nature. There is scepticism, therefore, both of utopian plans themselves, as well as the will and ability of fallible human beings working on the part of different nation states to bring them to fruition. In British foreign policy parlance this component is characterised as a love of 'pragmatism', which is often held up to be part and parcel of the DNA of the British people, as well as a highly prized element of British diplomacy over the years (Meyer 2010: 9, 51, 65, 132) . Totem of Conservative thinking in the UK, Margaret Thatcher, was highly critical of those who profess 'cloudy and unrealistic aspirations' without a grounding in the harsh vicissitudes of political realism, 'especially where European affairs are concerned' (Thatcher 1993: 552). In office, Thatcher expressed this historically attentive dimension of component of conservatism as follows: 'Utopia never comes, because we know we should not like it if it did' (Thatcher 1988). Quite simply, argues Christopher Meyer, the pragmatists have 'usually' been proved right (Meyer 2010: 200).

Blair and Cameron found much to recommend this worldview. Blair was always keen to explain that: 'We have a vision, but it is a vision that is practical'. The emphasis on being 'practical' and 'pragmatic' talks to the form of explanatory epistemology entailed in the realist reading of international affairs: 'we should deal with the world as it is, not how we want it to be. We should have confidence, both in our vision and our pragmatism' (Blair 1999a). David Cameron defined his foreign policy approach around the idea of liberal conservatism, but expressing similar sentiments: 
I am a liberal conservative, rather than a neo-conservative. Liberal - because I support the aim of spreading freedom and democracy, and support humanitarian intervention. Conservative - because I recognise the complexities of human nature, and am sceptical of grand schemes to remake the world (Cameron 2006).

Combatting what they sensed to be the perils of too 'idealistic' a conception of foreign policy, Hague developed the definition three years later, using Thatcher's critique of the 'utopianism' of liberalism to construct the Conservative position:

That is why David Cameron and I have spoken in recent years of our approach to foreign affairs being based on 'Liberal Conservatism' in that we believe in freedom, human rights and democracy and want to see more of these things in other nations. But Conservative, because we believe strongly in the continued relevance of the nation state and are sceptical of grand utopian schemes to remake the world (Hague 2009).

In 2011, Hague exemplified the reassertion of traditional conservative principles within British foreign policy by emphasising the pluralist conception of international society: 'Our Party's view of foreign policy is guided by our liberal conservatism: our sense of optimism and unquenchable faith in human nature, coupled with respect for the history and culture of other nations' (Hague 2011b). The conservative tradition, then, displays a scepticism, not that grand designs are irrelevant, but that in their design and implementation they need to reflect 'realities' on the ground, politically, diplomatically, economically and militarily.

\section{ii. Bandwagoning with the US}

Conservatives believe the national interest should come first, but that it is, and should not be, the only consideration for foreign policy decision-makers. In Britain conservatives ask, how can London policy-makers secure the nation's interest when, since the end of Empire, the UK patently no longer possesses the economic or military means to impose its will on the rest of the world by force or subtler forms of coercion? The answer has been to develop strong multilateral alliances, especially through the articulation of an Atlantic-looking foreign policy posture and a cautious, sceptical even, stance on the EU (Hall \& Rengger 2005: 78-79).

We see this playing out in two ways in foreign policy since 1997. The first is that Prime Ministers from both main parties have accepted that Britain should continue to play a world role in spite of its diminished political and economic status. In other words, recognition of the realities of international politics cannot quite prompt the British establishment to give up on its history, not least because they see their foreign policy inheritance as expressive of a public consensus on the appropriate ambitions for Britain in the world. As Blair put it in his memoirs: 'It's not a reason for doing anything, by the way, but the British, whatever they say, prefer their Prime Ministers to stand tall internationally' (Blair 2010: 410). Likewise, Hague unashamedly linked his foreign policy to the 'great' British traditions in a 2009 speech to the think-tank, the International Institute for Strategic Studies (IISS): 'The citizens of Britain have always been restless in trying to improve the wider world and global in our outlook' (Hague 2009). The 2010 SDSR, which announced large cuts in the defence budget, nevertheless opened with: 'Our country has always had global responsibilities and global ambitions. We have a proud history of standing up for the values we believe in and we should have no less ambition for our country in the decades to come.' (HM Government 2010a: 3). The Conservatives' return to power in 2010 did not, therefore, encourage a break in the strategic vision embodied by New Labour. As Christopher Martin has observed: 'The policy 
of the Coalition is that of all UK governments since 1945: the UK is a global player with global interests' (Martin 2011: 187).

One way of achieving this goal, as always since 1945, has been to use the leverage provided by the 'special relationship' with the US as a prop to Britain's global ambitions. 'The fact is that Britain just cannot achieve the things we want to achieve in the world unless we work with the world's superpower. So when it comes to the special relationship with America, Conservatives feel it, understand it and believe in it' (Cameron 2006). Hague was resolutely ideological about the centrality of the US to British foreign policy under a Conservative government:

Before we come into government, we want to have the deepest possible understanding of how foreign policy should be conducted and in doing so we are looking at many questions afresh. But in one thing we are clear from the onset: our relationship with the United States is central to our foreign policy, and will be one of deep and enduring partnership (Hague 2006).

Hague and Cameron repeated several times that their relationship with the US would be 'solid but not slavish'- an implicit criticism of Blair and an echo of the Liberal Democrat refrain (see Vickers 2011a: 205). However, beyond the slight rhetorical difference the emphasis on the Atlantic alliance was the same: 'The US-UK relationship is still special, still fundamental to both countries, still thriving and still a cornerstone of stability in the world' (Hague 2010). As the Conservative-Liberal agreement in May 2010 had it, relations with the US would be 'strong, close and frank'; with India and China they would be 'special' and with the EU, predictably, they would be a New Labour-esque blend of 'constructive' and 'positive' with Britain seeking to fend off further commitments across a range of policy sectors in the EU whilst at the same time claiming to be playing a 'leading role' (HM Government 2010b: 19-20; Daddow 2011) - 'leading from the edge' as Patrick Holden has described it (Holden 2011).

The second way in which we see this tradition playing out is that both prime ministers have favoured dealing with international crises in an alliance with the US and/or NATO (Vickers 2011a: 205), although both have enacted closer bilateral military co-operation with key partners such as France, as illustrated by the December 1998 St Malo agreement and the Lancaster House agreements of November 2010 (Holden 2011: 166-67; Dover and Phythian 2011: 423). These concords were facilitated by shared interests, a similar perception of the two countries' 'ranking' in global institutions and the urgent need to cut defence costs in an era of austerity. In contrast, the EU in general and its Common Foreign and Security Policy (CFSP) in particular ranked lower in both governments' priorities. The EU was not used during the military phase of the Kosovo intervention, nor obviously in Iraq, nor even in Libya, although this was not so much due to British obstruction as to German opposition to intervention. Military operations launched under the European Security and Defence and Policy (ESDP), though supposedly supported by the New Labour government since the St Malo agreement, saw little actual British military engagement, whether it was in Congo or off the Horn of Africa. Britain did, however, provide the headquarters for operation Atalanta, the EU's counter-piracy effort off the coast of Somalia (Martin 2011: 192).

Reflecting popular Conservative policy priorities, the Coalition government put explicit limits on its engagement in the EU's CFSP when it proposed to: 'support EU missions whether military or civilian - which are in the UK's national interest, which offer good value for money, have clear objectives and, in the case of military missions, only where it is clear that NATO is not planning to intervene' (HM Government 2010a: 62). This statement of intent exhibits both the cautious approach to 'Europe' that has been a characteristic feature of 
the bounded liberal foreign policy tradition, as well as the more ideologically-driven scepticism of the EU on 'sovereignty' grounds that has been a feature of post-war Conservative Party debates more specifically (Hall and Rengger 2005: 78).

\section{iii. Collective action in an interdependent world}

The third component of the UK conservative tradition in international affairs has come to be the acceptance of classical liberal mode of economic organisation and a reification of the ubiquitous term 'globalisation' as a means of making sense of the spectacular technological advances of the last four decades. Unfortunately, globalisation in the early years of the twenty first century has increasingly shown state leaders its darker sides (through the construction of global terrorist networks and organised crime) as well as the economic and strategic benefits that were much heralded at the end of the Cold War. As Blair put it in his 2002 Labour Party Conference speech: 'Globalisation and technology open up vast new opportunities but also cause massive insecurity' (Blair 2002). UK foreign policy-makers have, therefore, to grapple with the problem of achieving security in this much changed or 'new' world, via collective action in international organisations.

New Labour and the Conservative Party concurred that the 'new' world was defined by globalisation and interdependence. As Blair famously explained in his Chicago speech:

Today the impulse towards interdependence is immeasurably greater. We are witnessing the beginnings of a new doctrine of international community. By this I mean the explicit recognition that today more than ever before we are mutually dependent, that national interest is to a significant extent governed by international collaboration and that we need a clear and coherent debate as to the direction this doctrine takes us in each field of international endeavour...Global financial markets, the global environment, global security and disarmament issues: none of these can be solved without intense international co-operation (Blair 1999c).

However, this 'new' world was threatened by new dangers - or heightened awareness of older dangers, depending on one's perspective. They include religious extremist terrorism, transnational organised crime, nuclear proliferation and climate change, all of which are transnational in organisation and globalised in intent. Many of the security policies Blair put in place at home and abroad after 1997 were rationalized with reference to liberal thinking on globalization and interdependence (Bevir 2005: 128), whereby a threat somewhere around the globe was held to pose a threat anywhere in the globe. After 9/11 in particular, Blair's policies became 'themed around the perception of an apocalyptic security threat, namely the potential axis of rogue states with terrorist groups' (Dyson 2011: 72).

On the fifth anniversary of 9/11, Cameron defined the terrorist threat in words which were virtually indistinguishable from those uttered by Blair in his Chicago speech:

9/11 alerted us all to a security threat on a new and unprecedented scale... to a world of connections and complexity, conflating religion, foreign policy, domestic security policy, even economic policy in an unstable mix and to a world in which we urgently needed new thinking to match these frightening new challenges (Cameron 2006).

Under the cobweb model of liberalism, the concept of the national interest had to be redefined, from realist state-centrism to one more in tune with the collective solutions demanded of states living in a global village: 'Global challenges require global solutions. Global solutions require global alliances. Global alliances can't be constructed on the basis of 
narrow national self-interest. They have to be based on shared global values' (Blair 2010: 225). Countries could no longer ignore events happening in other countries since they were bound to have global ramifications. In Parliament he drew these themes together, justifying action in Kosovo with implicit reference to the dangers of letting the 'domino effect' take hold - of leaving localised trouble spots to simmer untended:

We must act to save thousands of innocent men, women and children from humanitarian catastrophe - from death, barbarism and ethnic cleansing by a brutal dictatorship - and to save the stability of the Balkan region, where we know chaos can engulf the whole of the European Union' (Blair 1999b; emphasis added).

The idea that a dictator left to his own devices can spread insecurity and crime beyond his borders is the theme of our final component of the bounded liberal tradition: antiappeasement.

\section{iv. 'Though shalt not appease'}

The final component of the post-1945 foreign policy tradition in the UK is a staunch 'antiappeasement' tradition, perhaps better expressed as the firm intention not to be accused of 'appeasing' seemingly revisionist powers or leaders. Historically, this 'dreaded word' has been associated with Foreign Office policy towards, most notably, Italy's invasion of Abyssinia in 1935 and during Serb aggression Bosnia in the 1990s (Meyer 2010: 216 and 249). Memories of these sorry episodes resonate in the collective diplomatic consciousness in the UK, as well as tapping into a wider Western meta-narrative back to the Versailles Treaty and the Munich Agreement which, the moral of the lesson has it (Rasmussen 2003), left dictators to rampage unchallenged, costing much 'blood and treasure' to rectify. Dealing with dictators sooner rather than later has become the ambition, although debates will continue to rage about when the international community is able to judge when a dictator has gone too far, and what lawful and legitimate action can remedy the situation. This 'lesson' begs as many questions as it supplies answers, raising the age old questions about 'just wars' and proportionate means of executing them militarily or via actions short of hard intervention, such as sanctions and the freezing of economic assets. If the previous component of the bounded liberal tradition is all about locating the modern state in political time, as it were, this component is about placing it spatially - drawing the boundaries of the contemporary 'international community' and the dividing lines between 'good' states (the insiders of international society) and 'bad' states (the outsiders).

When talking about Kosovo, Blair always reminded his audience that 'we have learned twice before in this century that appeasement does not work', calling for immediate action to check the 'evil dictator' Slobodan Milosevic (Blair 1999c). The leaders of pariah states which threaten international order, such as Colonel Nasser of Egypt during the Suez crisis, Milosevic in the Serbia, 'the Taleban' in Afghanistan, Saddam Hussein in Iraq and latterly Muammar Gaddafi, can all be slotted neatly into the anti-appeasement tradition when the decision has been taken to deal with them. As Cameron explained to the UN after Libya: 'And on this occasion a coalition of nations across the Western and Arab world had the will to act. In so doing, they stopped Benghazi from joining Srebrenica and Rwanda in history's painful roll call of massacres the world failed to prevent' (Cameron 2011c). At the same time, Kim Jong Il, Mahmoud Ahmedinijad and Robert Mugabe are constructed by the spokespeople for the international community as shadowy 'others' who may or may not be dealt with in the future, but whose actions speak ill of them and their states. As for Blair in Kosovo, so Cameron for Libya: "we should not stand aside while [Gaddafi] murders his own 
people' (Cameron 2011b, col.704). Cameron blended humanitarian and self-interested motives when explaining his policy:

Some have argued that we should leave it to others because there is not sufficient British national interest at stake. I believe that argument is misplaced. If Gaddafi's attacks on his own people succeed, Libya will become once again a pariah state, festering on Europe's border, and a source of instability exporting terror beyond its borders. It will be a state from which literally hundreds of thousands of citizens could try to escape, putting huge pressure on us in Europe. We should also remember that Gaddafi is a dictator who has a track record of violence and support for terrorism against our country' (Cameron 2011b, col.708).

The history of past misdemeanours, present repression and the likely future of continued instability in Libya and North Africa blend seamlessly together in the way Cameron fitted Gaddafi into the metanarrative of the century's great dictators. Left unchecked, he suggests, the international community will be far worse off (in security terms as well as strategically and economically) than if it acts now. Thatcher had used just that logic to argue, out of office in 1992, for firmer British action on Bosnia: "waiting until the conflict burns itself out will not only be dishonourable but also very costly: refugees, terrorism, Balkan wars drawing in other countries and worse' (quoted in Meyer 2010: 245).

This section has surveyed the elements of what we take to be the post-1945 tradition of thought on international affairs in the UK: a cautious approach centring on a scepticism about human nature and a loss of faith in 'grand schemes' to remake the world; an Atlanticfocussed foreign policy strategy that seeks to achieve in the present what Britain was never quite able to sustain after the Second World War - a 'great' global role; acceptance of the liberal model of the contemporary global political economy and the demand for collective action that has resulted from the growth in consciousness of transnational security challenges; and a propensity to draw boundaries within the international system between 'us' good citizens and 'them' dictators. Throughout the above we have attempted to show how the conservative tradition has helped shape the foreign policy thought of New Labour and the Conservatives. In the next section we will home in on the elements of Blair and Cameron's discourse dealing with the conditions they set down for intervention in the affairs of another state. This will enable us to highlight the dynamic nature of the dialogue the governments of 1997-2010 and 2010-present have been having with the bounded liberal tradition, and therefore to argue that nothing in this tradition predisposed the governments to think and act as they have. The conditions for intervention each has set down reflect particular dilemmas facing the governments of the day.

\section{Setting the conditions for engagement and intervention}

So far in the article we have traced the elements of the bounded liberal tradition that have most obviously been at play in shaping recent British foreign policy thought. However, we are aware that it would be an over-simplification to paint this tradition as determining Britain's responses to the Kosovo and Libya crises, as if British foreign policy thought is so highly structured it leaves no room for agency to explain policy outcomes. To make this case, the following section will explore the difference between 'engagement' on the one hand and 'intervention' on the other, drawing out the nuances between Cameron and Blair's approaches. This distinction will then be illustrated with reference to the 'conditions' that each placed on their willingness to engage Britain militarily in the affairs of another state. We will suggest that the crucial variables accounting for the change of emphasis within interventionist discourses from Blair to Cameron are: the latter's willingness to turn away 
from a 'neo-conservative' reading of the UK foreign policy tradition, which never gained widespread acceptance in the Conservative Party; events in Iraq from 2003 which helped further undermine the appeal of a neo-conservative approach to foreign policy; and Hague's leadership of the Foreign Office which took UK foreign policy back towards the pragmatic post-1945 traditions we have outlined above.

In his article on Conservative foreign policy traditions, Matt Beech quotes an extract from the Conservative Party website which defined Conservative foreign policy as aiming to defend British national interests by renewing and reinforcing 'our engagement with the rest of the world'. Beech aptly notes that 'engagement' is not the same as 'intervention' - the Conservatives have always engaged in international affairs; they are not isolationists. Engagement flows from the idea that crisis prevention can be achieved before intervention becomes necessary and is linked in Conservative thinking to international aid and development (Vickers 2011a: 212), as well as to the anti-appeasement tradition evident in British foreign policy discourse since 1945. Intervention implies something stronger than engagement: 'a willingness to involve one's nation in a more active' way, usually through military or humanitarian instruments (Beech 2011: 356-57).

The Foreign Affairs segment of the Conservative Party website after the 2010 general election victory read that 'the Government believes that Britain must always be an active member of the global community, promoting our national interests while standing up for the values of freedom, fairness and responsibility', which nodded towards an ethical intent without mentioning the tarnished idea of humanitarian intervention per se (Conservative Party undated). In the October 2010 National Security Strategy and SDSR it also looked as if Conservative sights would firmly be set on engagement short of intervention (Dover and Phythian 2011: 435-36). For Klaus Dodds and Stuart Elden, this demonstrated a victory of traditional conservative values for Cameron over some on the right of the party, such as Michael Gove (Dodds \& Elden 2008: 355-56), who were influenced by ideas circulating in the Henry Jackson Society. This brought together American and British neo-conservative politicians from the left and right to promote the view:

... that liberal democracy should be spread across the world; that as the world's most powerful democracies, the United States and the European Union - under British leadership - must shape the world more actively by intervention and example; that such leadership requires political will, a commitment to universal human rights and the maintenance of a strong military with global expeditionary reach' (quoted in Dodds \& Elden 2008: 351).

In a speech on the fifth anniversary of 9/11 Cameron signalled the return to a more cautious, pragmatic era for British foreign policy by declaring himself to be emotionally and rationally committed to the Anglo-American relationship but certainly no 'neo-conservative' in foreign policy (Cameron 2006). In office, and keen to steer the party between the Scylla of Major's moral bankruptcy over Bosnia and the Charybdis of Blair's adventurism in Iraq, Prime Minister Cameron kept his cards relatively close to his chest until the Libyan dilemma forced him to consider the practicalities of undertaking a new military intervention when there was such obvious public unease about an operation in the febrile atmosphere post-Iraq. The basic moral position Cameron and Hague adopted (that the Libyan people needed support against Gaddafi) immediately obviated any comparison with Major; meanwhile, the turn to regional support and wider multilateralism in the NATO context helped silence the voices of the neoconservatives in the Party, legitimising the intervention in a way that Blair could not manage over Iraq. A study of the conditions each leader settled on will elucidate the deeper dynamics of this return to a bounded liberal foreign policy. 
In his 1999 doctrine of international community speech, Blair mentioned five conditions that he believed should inform discussion of whether or not to intervene in a given crisis situation:

First, are we sure of our case? War is an imperfect instrument for righting humanitarian distress; but armed force is sometimes the only means of dealing with dictators. Second, have we exhausted all diplomatic options?...Third, on the basis of a practical assessment of the situation, are there military operations we can sensibly and prudently undertake? Fourth, are we prepared for the long term?...And finally, do we have national interests involved ? (Blair 1999c)

As Ralph has commented, these conditions were subjective or self-centred, in the sense that the authority defining whether they were met was never defined and, significantly, the 'legitimacy test' of convincing others of the need for intervention was lacking. Following Andrew Linklater, Ralph concludes that 'Blair's doctrine should have included a sixth test: are others sure of the case for war' (Ralph 2011: 127; emphasis in original). This may be why Cameron and Hague insisted instead on what had been missing in the Iraq war (although they supported it at the time); that is, explicit support from the United Nations (UN) and a commitment to working with partners in multilateral organisations. The Libya dilemma for Cameron was policy-led, but entailed a further dilemma about how to present the case for intervention when public appetite for what might have been perceived as British adventurism was so restricted.

Cameron's answer was to rewrite the Blair doctrine by spelling out different conditions under which such intervention could be acceptable within UK foreign policy. Cameron seems to have formed the same opinion as Jason Ralph, that: 'The doctrine of international community may have been damaged by its authors in New Labour but it does not mean it cannot properly inform British foreign policy' (Ralph 2011: 138). In contrast to Blair, therefore, in 2006 Cameron defined his approach to intervention as revolving around the following considerations:

First, that we should understand fully the threat we face. Second, that democracy cannot quickly be imposed from outside. Third, that our strategy needs to go far beyond military action. Fourth, that we need a new multilateralism to tackle the new global challenges we face. And fifth, that we must strive to act with moral authority (Cameron 2006).

All but the first of the 2006 conditions were meant to distance the Conservative approach from that of Blair in a number of ways. First, Cameron did not wish to impose democracy on Libya in the way Blair had attempted, with the Bush administration, to impose democracy on Iraq. Second, Cameron did not wish to appear to be ignoring the need for a civilian-military reconstruction strategy after the military phase of operations had concluded, as had been the case for the post-conflict phase in Iraq. Third, in the case of the Libyan intervention, there was added support from the Arab League and no British troops on the ground, which in Cameron and Hague's eyes enhanced the legitimacy and feasibility of their approach.

Libya encouraged the key players (Britain, France and the US) to refine the case for intervention to the bare bones, taking Cameron from the realm of the philosophical to the realm of the practical, and reducing the list from five conditions to three tests:

Throughout, we were clear that three tests would need to be met in order to justify military action. Demonstrable need, regional support and a clear legal 
basis. These were met. Demonstrable need because Gaddafi had so flagrantly ignored the demands of two UN Security Council Resolutions to end the violence against his people. Regional support - because it was the people of Libya who first called for protection from attack. And because they were supported in that call by the Gulf Co-operation Council, the Arab League and the three African members of the Security Council. And legal because of the clear mandate provided by the UN Security Council Resolution (Cameron 2011a).

Cameron therefore maintained that, unlike Iraq, Libya was in clear breach of a UN Security Council resolution (it was lawful); unlike Iraq, the Libya intervention was carried out with the will of the Libyan people (it was legitimate); and unlike Iraq, there was a clear mandate for operations which would not necessarily end in 'regime change' (this was no open-ended commitment). For example, in their published letter to publics around the world in April 2011, Barack Obama, David Cameron and Nikolas Sarkozy (2011) stressed that 'Our duty and our mandate under U.N. Security Council Resolution 1973 is to protect civilians... It is not to remove Qaddafi by force', although ominously they added: 'But it is impossible to imagine a future for Libya with Qaddafi in power' given the evidence on his war crimes then being gathered by the International Criminal Court. Even though the overthrow of Gaddafi was the logical outcome of a military intervention, presentationally-speaking Cameron had to be seen to be distancing Libya from Iraq and the stress was always, therefore, on the legal basis for operations. ${ }^{1}$

Reflecting on the 'success' of Libya, Cameron severely restricted the scope for the operation to turn into a Blairite crusade:

Some will look at Libya and ask 'is this a new British doctrine for intervention?' Next time, will we just charge in regardless? My answer is 'no'. Look at the reasons for the success of the Libya campaign. We set limited goals and stuck to them. We worked with allies. We went through the United Nations. We had the support of the people. We didn't presume to tell people what sort of government they should have (Cameron 2011d).

In a speech to the UN in September 2011, Cameron added that it had given a boost to the international community which, he said, had 'found its voice in Libya. We must not now lose our nerve'. He continued by listing Iran and Syria as countries of concern, democratically speaking, although the speech as a whole was so hedged with cautionary tales of democracy needing to grow from below rather than being imposed from above, that only on certain readings could it be taken as echoing Blairite overconfidence in the will of the democratic 'West' to export democracy elsewhere in the global community of states (Cameron 2011c).

Any potentially crusading zeal on the part of Cameron had already been reined in by memories of Blair's hubris in Iraq. However, there is a crucial further factor to consider - the conditions of foreign policy-making within Whitehall since the advent of the Coalition government in 2010. With Hague in post, core tenets of post-1945 UK foreign policy have successfully been re-imposed on an errant Downing Street (1997-2010) by a Foreign Secretary keen to restore a more ordered and balanced approach to foreign policy decisionmaking. Hague insisted on making a break from the dysfunctional 'kitchen cabinet' - what

\footnotetext{
${ }^{1} \mathrm{We}$ are grateful to Tim Bale for minding us of this key tension in the discourses surrounding the two operations.
} 
Anthony Seldon calls Blair's 'denocracy' and Meyer Blair's 'sofa government' (Seldon 2005; Meyer 2010: 33). This had led to the overt control of foreign policy in the hands of the Prime Ministers and his small team of advisers, which was both undemocratic and dangerous: 'Foreign policy was under the watchful gaze of Downing Street, even if Blair and his team did not always know where they wanted to take it' (Daddow 2011: 54). Crucially, and in an echo of the Thatcher years (Meyer 2010: 15 and 150), the Foreign Office and, to a large extent, the Cabinet had been left outside the policy-making process in the run-up to the Iraq war, leading more than the odd former Cabinet minister to float the idea that this had been a 'misuse of power' (Short 2005). According to one former Foreign Secretary this was the culmination of a long period of decline for the Foreign Office. Nowadays, 'we are used to Prime Ministers scurrying across the world to announce new decisions and initiatives' while Foreign Secretaries 'hover in the background of the main event, offering advice which may or may not be used' (Hurd 2011:30).

In his IISS speech given shortly before taking office, Hague promised to restore the primacy of the Foreign Office in decision-making and to establish a regular National Security Council as a Cabinet committee, where the Foreign Office, Ministry of Defence, Home Office and Department for International Development would be represented and which would be the real centre of external decision-making (Hague 2009). Hague reported in 2011 that he was well on the way to achieving this objective even after swingeing budget cuts across all departments of government, creating greater balance within the policy process between Downing Street and Whitehall (Hague 2011a). Along with memories of Iraq, the restoration of the Foreign Office as a source of genuine foreign policy advice to the Prime Minister has given fresh balance to Prime Minister-Foreign Secretary relations, such that they are now more equal under Cameron and Hague than ever they appear to have been under Blair and his Foreign Secretaries - Robin Cook, Jack Straw and Margaret Beckett.

\section{Conclusion}

We draw two conclusions from the preceding analysis. The first is that attentiveness to the language of the conditions for intervention put in place by Blair and Cameron reveals how each prime minister looked to key traditions in British foreign policy back to 1945 when faced with dilemmas over humanitarian crises in the modern state system. For Blair, the Conservatives under John Major had failed to grasp the realities of Britain's role in the world and he charted what he liked to speak of as a 'new' foreign policy with ethical concerns at its core. In so doing, Blair showed himself to be attuned to certain idealist moments in the history of British foreign policy; but had he been attentive to the recent history of conservatism and realism, Blair may have appreciated that what he was in fact doing was bringing back in a neglected bounded liberal tradition from more recent prime ministers that in his rush to write off as 'old hat' he ignored at his peril. Iraq saw Blair switch from the prudent engagement he professed to seek for Britain in the world to an activist interventionism that rode roughshod over the principles he had tried to restore to the establishment mindset. Blair's neglect of the Foreign Office as a source of policy advice was just the most noticeable indicator of a highly restrictive decision-making process over which Downing Street had firm control. Blair's highly personalised leadership of foreign policy was echoed in the nature of the conditions he claimed needed to be satisfied to justify further interventions. As long as Blair was convinced of the case, it was really rather immaterial what others thought. In Blair's mind his interventions were legitimate - the problem was that not many key leaders or nation states came to think the same.

The second conclusion is that the foreign policy ideas expounded by the Henry Jackson Society and other neo-conservative groups on the fringes of the Conservative Party were just that - on the edges of Conservative Party policy thought. Any influence they might 
have been able to exert was swiftly nullified when, in government, Cameron appointed the influential Thatcherite Hague as Foreign Secretary, with Michael Gove given a domestic berth as Education Secretary. Cameron instead looked to recent British foreign policy failures as his inspiration and in particular showed himself to be adept at learning about the perils of too expansive an interventionist posture from Blair's Iraq folly. Over Libya, Cameron re-positioned classic conservative traditions at the heart of his policy, giving his foreign policy the following key characteristics: a cautiousness about designing schemes for remaking the world around democratic - or any other - ideologically charged principles; an Atlanticist leaning towards the 'special relationship' linked to a pragmatic willingness to work with allies inside the EU or outside of NATO should such action help achieve a limited mission with a clear end-state; a constant concern to grapple with the nature of the 'modern' world and the pernicious security effects of complex interdependence; and a propensity to elucidate foreign policy principles in the context of the popular Western 'anti-appeasement' metanarrative. Of those features, the one that is most likely to lead Cameron into dangerous entanglements in the future might be the final one, but its pull is likely to be offset by the steadying hand of Hague at the Foreign Office, George Osbourne at the Treasury (Cameron's own 'inner circle') and a return to the bounded liberal tradition in British foreign policy more generally.

\section{References}

Beech, M. (2011) 'British Conservatism and Foreign Policy: Traditions and Ideas Shaping Cameron's Global View', British Journal of Politics and International Relations, Vol.13, No.3, pp.348-63.

Bevir, M. (2002) The Logic of the History of Ideas (Cambridge: Cambridge University Press).

Bevir, M. (2005) New Labour: A Critique (Abingdon and New York: Routledge).

Bevir, M. (2011) 'Political Science After Foucault', History of the Human Sciences, Vol.24, No.4, pp.81-96.

Bevir, M., Daddow, O. And Hall, I. (eds) (in preparation) Interpreting Global Security.

Bevir, M. and Rhodes, R.A.W (1999) 'Studying British Government: Reconstructing the Research Agenda', British Journal of Politics and International Relations, Vol.1, No.2, pp.215-239.

Bevir, M., Rhodes, R.A.W. and Weller, P. (2003) 'Comparative Governance: Prospects and Lessons', Public Administration, 81; repaginated online version available at: http://escholarship.org/uc/item/1bz222w3, 1-35. Accessed 28 October 2010.

Blair, T. (1999a) Euro statement, 23 February. Available at: http://webarchive.nationalarchives.gov.uk/20061004085342/number10.gov.uk/page1275, accessed 4 January 2012.

Blair, T. (1999b) House of Commons, 23 March, Col. 162. 
Blair, T. (1999c), 'Doctrine of the international community', speech to the Chicago Economic Forum, 24 April, available at http://keeptonyblairforpm.wordpress.com/blairspeech-transcripts-from-1997-2007/\#chicago, accessed 6 December 2011.

Blair T. (2002) Party Conference speech, Blackpool, available at: http://www.britishpoliticalspeech.org/speech-archive.htm?speech=185, accessed 17 January 2012.

Blair, T. (2010), A Journey (London: Hutchinson).

Bolaño, R. (2009) 2666: A Novel (Basingstoke and Oxford: Picador).

Bratberg, Ø. (2011) 'Ideas, Tradition and Norm Entrepreneurs: Retracing Guiding Principles of Foreign Policy in Blair and Chirac's Speeches on Iraq', Review of International Studies, Vol.37, No.1, pp.327-48.

Broad, M. and Daddow, O. (2010) 'Half remembered quotations from mostly forgotten speeches: the limits of Labour's European policy discourse', British Journal of Politics and International Relations, Vol.12, No.2, pp.205-222.

Cameron, D. (2006) 'A new approach to foreign affairs - liberal conservatism', speech to the British American Project, 11 September, available at http://www.conservatives.com/News/Speeches/2006/09/Cameron_A_new_approach_to_forei gn_affairs_liberal_conservatism.aspx, accessed 8 December 2011.

Cameron (2011a) PM statement to the House on Libya, 21 March, available at http://www.number10.gov.uk/news/libya-debate/, http://www.number10.gov.uk/news/libyadebate/, accessed 16 January 2012.

Cameron, D. (2011b) House of Commons, 21 March.

Cameron, D. (2011c) speech to UN General Assembly, New York, 22 September, available at: $\quad$ http://www.newstatesman.com/global-issues/2011/09/arab-world-region-libya-act, accessed 16 January 2012.

Cameron, D. (2011d) 'Foreign policy in the national interest', speech to the Lord Mayor's Banquet, 14 November, available at http://www.number10.gov.uk/news/lord-mayorsbanquet/, accessed 6 January 2012.

Clarke, M. (1988) 'The Policy-making Process', in M. Smith, S. Smith and B. White (eds) British Foreign Policy: Tradition, Change and Transformation (London: Hyman), pp.71-95.

Conservative Party (undated) 'Where we stand: foreign affairs', available at http://www.conservatives.com/Policy/Where_we_stand/Foreign_Affairs.aspx, accessed 4 January 2012.

Corthorn, P. \& Davis, J. (eds) (2008), The British Labour Party and the Wider World: Domestic Politics, Internationalism and Foreign Policy (London: Tauris). 
Daddow, O. (2009) “"Tony's War?" Blair, Kosovo and the interventionist impulse in British foreign policy', International Affairs, Vol.85, No.3, pp.547-60.

Daddow, O. (2011) New Labour and the European Union: Blair and Brown's Logic of History (Manchester and New York: Manchester University Press).

Daddow, Oliver and Gaskarth, Jamie (2011) 'Introduction: Blair, Brown and New Labour's Foreign Policy, 1997-2010', in O. Daddow and J. Gaskarth (eds) British Foreign Policy: The New Labour Years (Basingstoke and New York: Palgrave Macmillan), pp.1-27.

de Carmoy, G. (1971) 'Defence and Unity of Western Europe since 1958', in N. Waites (ed.) Troubled Neighbours: Franco-British Relations in the Twentieth Century (London: Weidenfeld and Nicolson), pp.344-74.

Dodds, K. and Elden, S. (2008) 'Thinking Ahead: David Cameron, the Henry Jackson Society and British Neo-conservatism', British Journal of Politics and International Relations, Vol.10, No.3, pp.347-63.

Dover, R. and Phythian, M. (2011) 'Lost Over Libya: The 2010 Strategic Defence and Security Review- An Obituary', Defence Studies, Vol.11, No.3, pp.420-444.

Dyson, S.B. (2009) The Blair Identity: Leadership and Foreign Policy (Manchester and New York: Manchester University Press).

Dyson, S.B. (2011) 'New Labour, Leadership, and Foreign Policy-making after 1997', in O. Daddow and J. Gaskarth (eds) British Foreign Policy: The New Labour Years (Basingstoke and New York: Palgrave Macmillan), pp.63-83.

Epstein, C. (2008) The Power of Words in International Relations: Birth of an Anti-Whaling Discourse (Cambridge, MA. and London: MIT Press).

Gaskarth, J. (2010) 'Coalition foreign policy is strikingly familiar', available at http://www.newstatesman.com/writers/jamie_gaskarth, accessed 6 January 2011.

Hague, W. (2006), 'The Special Relationship', speech to the School of Advanced International Studies, 17 February.

Hague, W. (2009), 'The Future of British Foreign Policy', speech to the International Institute for Strategic Studies, 21 July, available at: http://www.conservatives.com/News/Speeches/2009/07/William_Hague_The_Future_of_Brit ish_Foreign_Policy.aspx, accessed 17 January 2012.

Hague, W. (2010), 'International Security in a networked world', speech to Georgetown University, 17 November.

Hague, W. (2011a) 'The best diplomatic service in the world: strengthening the Foreign and Commonwealth Office as an institution', speech at the Foreign and Commonwealth Office, available at http://www.fco.gov.uk/en/news/latest-news/?view=Speech\&id=652930982, accessed 4 January 2012. 
Hague, W. (2011b) speech to the Conservative Party conference, 5 October, available at: http://www.conservatives.com/News/Speeches/2011/10/Hague_Changing the_way_we_cond uct_foreign_policy.aspx, accessed 17 January 2012.

Hall, I. And Rengger, N. (2005), 'The Right that Failed? The Ambiguities of Conservative Thought and the Dilemmas of Conservative Practice in International Affairs', International Affairs, Vol.81, No.1, pp.69-82.

Heath, E. (1969) 'Realism in British Foreign Policy', Foreign Affairs, Vol.48, No.1, pp.3950 .

HM Government (2010a) Securing Britain in an Age of Uncertainty: the Strategic Defence and Security Review, Cm 7948, October.

HM Government (2010b) 'The Coalition: our programme for government', available at http://www.libdemvoice.org/the-full-coalition-agreement-19612.html, accessed 10 January 2012.

Holden, P. (2011) 'Still "Leading from the Edge"? New Labour and the European Union', in O. Daddow and J. Gaskarth (eds) British Foreign Policy: The New Labour Years (Basingstoke and New York: Palgrave Macmillan), pp.157-69.

Hurd, D. (2011) Choose Your Weapons: The British Foreign Secretary- 200 Years of Argument, Success and Failure (London: Phoenix).

Kabele, J. (2010) 'The Agency/Structure Dilemma: A Coordination Solution', Journal for the Theory of Social Behaviour, Vol.40, No.3, pp.314-38.

Kennedy, P. (1985) The Realities behind Diplomacy: Background Influences on British External Policy 1865-1980 (London: Fontana).

Martin, C. 'The Con-Lib Agenda for National Security Strategy', in S. Lee and M. Beech (eds) 'The Cameron-Clegg Government: Coalition Politics in an Age of Austerity' (Basingstoke and New York: Palgrave Macmillan), pp.187-202.

Meyer, C. (2010) Getting Our Way. 500 Years of Adventure and Intrigue: The Inside Story of British Diplomacy (London: Phoenix).

Morgenthau, H.J. (1985) Politics among Nations: The Struggle for Power and Peace, $6^{\text {th }}$ edn (New York: Knopf)

Morris, J. (2011) 'How Great is Britain? Power, Responsibility and Britain's Future Global Role', British Journal of Politics and International Relations, Vol.13, No.3, pp.326-347.

Obama, B., Cameron, D. and Sarkozy, N. (2011) 'Libya's Pathway to Peace', available at: http://www.nytimes.com/2011/04/15/opinion/15iht-edlibya15.html, accessed 17 January 2012.

Poulsen, B. (2009) 'Competing Traditions of Governance and Dilemmas of Administrative Accountability: The Case of Denmark', Public Administration, Vol.87, No.1, pp.117-31. 
Wilkinson, K. (2011) 'Organised Chaos: An Interpretive Approach to Evidence-based Policy Making in Defra', Political Studies, Vol.59, No.4, pp.959-977.

Press Association (1999) 'Foreign Office savaged over arms to Africa', 9 February, available at: http://www.guardian.co.uk/politics/1999/feb/09/foreignpolicy.politicalnews, accessed 17 January 2012.

Ralph, J. (2011) 'A Difficult Relationship: Britain's "Doctrine of International Community" and America's "War on Terror"', in O. Daddow and J. Gaskarth (eds) British Foreign Policy: The New Labour Years (Basingstoke and New York: Palgrave Macmillan), pp.123-38.

Rasmussen, M.V. (2003) 'The History of a Lesson: Versailles, Munich and the Social Construction of the Past', Review of International Studies, Vol.29, No.4, pp.499-519.

Rhodes, R.A.W. (2007) 'Understanding Governance: Ten Years On', Organization Studies, Vol.28, pp.1243-1264.

Saville, J. (1993) The Politics of Continuity: British Foreign Policy and the Labour Government 1945-46 (London: Verso).

Seldon, A. (2005) Blair (London: Free Press).

Shlaim, A. (1977) 'The Foreign Secretary and the Making of Foreign Policy', in A. Shlaim, P. Jones and Sainsbury, British Foreign Secretaries since 1945 (London: David \& Charles), pp.13-26.

Short, C. (2005) An Honourable Deception? New Labour, Iraq and the Misuse of Power (London: Free Press).

Smith, M.J. (2008) 'Re-Centring British Government: Beliefs, Traditions and Dilemmas in Political Science’, Political Studies Review, Vol.6, No.2, pp.143-54.

Thatcher, M. (1988) Speech to the College of Europe, 20 September. Available online at: www.margaretthatcher.org/speeches/displaydocument.asp?docid=107332, accessed 14 October 2010.

Thatcher, M. (1993) The Downing Street Years (New York: HarperCollins Publishers).

Theakston, K. (2004) 'The Changing Role of the Foreign Secretary', in K. Theakston (ed.) British Foreign Secretaries since 1974 (London: Routledge), pp.1-46.

Vickers, R. (2011a) 'The Con-Lib Agenda for Foreign Policy and International Development', in S. Lee and M. Beech (eds) The Cameron-Clegg Government: Coalition Politics in an Age of Austerity (Basingstoke and New York: Palgrave Macmillan), pp.203-17.

Vickers, R. (2011b) The Labour Party and the World, Volume 2: Labour's Foreign Policy since 1951 (Manchester: Manchester University Press).

Walker, R.B.J. (1993) Inside/Outside: International Relations as Political Theory (Cambridge: Cambridge University Press). 
Waltz, KJ.N. (1959) Man, the State and War (New York: Cambridge University Press).

Wilkinson, K. (2011) 'Organised Chaos: An Interpretive Approach to Evidence-based Policy Making in Defra’, Political Studies, Vol.59, No.4, pp.959-977. 